\title{
Geology
}

\section{First Toba supereruption revival}

Meng-Yang Lee, Chang-Hwa Chen, Kuo-Yen Wei, Yoshiyuki lizuka and Steven Carey

Geology 2004;32;61-64

doi: $10.1130 / G 19903.1$

\section{Email alerting services}

\section{Subscribe}

Permission request click www.gsapubs.org/cgi/alerts to receive free e-mail alerts when new articles cite this article

click www.gsapubs.org/subscriptions/ to subscribe to Geology

click http://www.geosociety.org/pubs/copyrt.htm\#gsa to contact GSA

Copyright not claimed on content prepared wholly by U.S. government employees within scope of their employment. Individual scientists are hereby granted permission, without fees or further requests to GSA, to use a single figure, a single table, and/or a brief paragraph of text in subsequent works and to make unlimited copies of items in GSA's journals for noncommercial use in classrooms to further education and science. This file may not be posted to any Web site, but authors may post the abstracts only of their articles on their own or their organization's Web site providing the posting includes a reference to the article's full citation. GSA provides this and other forums for the presentation of diverse opinions and positions by scientists worldwide, regardless of their race, citizenship, gender, religion, or political viewpoint. Opinions presented in this publication do not reflect official positions of the Society.

\section{Notes}




\title{
First Toba supereruption revival
}

\author{
Meng-Yang Lee* ]_ Institute of Earth Sciences, Academia Sinica, P.O. Box 1-55, Nankang, Taipei, Taiwan, Republic of \\ Chang-Hwa Chen J- China \\ Kuo-Yen Wei Department of Geosciences, National Taiwan University, P.O. Box 13-318, Taipei, Taiwan, Republic of China \\ Yoshiyuki lizuka Institute of Earth Sciences, Academia Sinica, P.O. Box 1-55, Nankang, Taipei, Taiwan, Republic of China \\ Steven Carey Graduate School of Oceanography, University of Rhode Island, Narragansett, Rhode Island 02882, USA
}

\begin{abstract}
Little has been known about the earliest Toba eruptive episodes that created the largestknown caldera complex of Quaternary age. Here we report evidence for the eastward dispersal of the oldest Toba tuff in South China Sea sediments to $2500 \mathrm{~km}$ away from the source. The tephra deposits occur below the Brunhes-Matuyama geomagnetic boundary (778 ka) and slightly above the Australasian microtektite layer (793 ka). Calibrated by astronomically tuned oxygen isotope stratigraphy, the middle Pleistocene Toba eruption occurred during the deglaciation at $788 \pm 2.2 \mathrm{ka}$, according to the tephra occurrence between marine isotope stages 20 and 19. This refined age is in good agreement with the ${ }^{40} \mathrm{Ar} /{ }^{39} \mathrm{Ar}$ date of $800 \pm 20 \mathrm{ka}$ for the Toba tephra (layer D) from Ocean Drilling Program (ODP) Site 758, but significantly younger than the commonly cited Ar/Ar age of $840 \pm$ $30 \mathrm{ka}$. The eruption expelled at least $800-1000 \mathrm{~km}^{3}$ dense-rock-equivalent of rhyolitic magma on the basis of the widespread tephra-fall deposit in the basins of the Indian Ocean and the South China Sea. In spite of its exceptional magnitude, the timing of this major eruption does not indicate a causal linkage between this event and a long-term global climatic deterioration.
\end{abstract}

Keywords: Toba tuffs, microtektites, tephrochronology, explosive eruptions, climate effects.

\section{INTRODUCTION}

The Toba caldera complex in northern $\mathrm{Su}-$ matra is a $100 \times 30 \mathrm{~km}$ topographic depression of several overlapping calderas resulting from four major eruptions during the Quaternary (e.g., Knight et al., 1986; Chesner et al., 1991). Among the largest volcanic calderas on Earth, the present perimeter of the complex has been significantly affected by the youngest Toba eruption that expelled $>2800 \mathrm{~km}^{3}$ dense-rock-equivalent (DRE) of rhyolitic magma at 74,000 yr B.P. (Ninkovich et al., 1978; Rose and Chesner, 1987). The coincidence of this exceptionally large eruption with the transition from marine isotope stage 5 to stage 4 has led to the proposition that it triggered a major volcanic winter and consequently the onset of the last glaciation (e.g., Rampino and Self, 1992, 1993). The volcanic cataclysm, marked by the occurrence of widespread tephras and climatic imprints, provides a synchronous horizon for correlation between the terrestrial, marine, and ice-core chronostratigraphies (e.g., Ninkovich et al., 1978; Dehn et al., 1991; Zielinski et al., 1996). The late Pleistocene Toba eruption was preceded by eruption of the middle Toba tuff at $501 \mathrm{ka}$ (Chesner et al., 1991), the oldest Toba tuff at 840 ka (Diehl et al., 1987), and the Haranggoal Dacite tuff at 1.2 Ma (Nishimura et al., 1977). These voluminous ignimbrite eruptions also produced widespread tephra-fall deposits

*E-mail: monyoung@earth.sinica.edu.tw. over an extensive area (e.g., Ocean Drilling Program [ODP] Site 758 on the Ninetyeast Ridge in the Indian Ocean; Dehn et al., 1991); these deposits serve as useful markers for dating Quaternary archaeological sites on the Indian subcontinent (e.g., Shane et al., 1995; Westgate et al., 1998).

The oldest Toba tuff is the first quartzbearing Toba tuff and was erupted from the Porsea caldera in the southern half of Toba. Knight et al. (1986) estimated the volume of the rhyolitic ignimbrite within the caldera to be $\sim 500 \mathrm{~km}^{3}$ DRE. This volume is considered to be a minimum because the ignimbrite's extent may be much greater and the eruption likely produced massive tephra-fall deposits. Despite its large volume, there is no deep-sea record documenting the distribution of the associated tephra fall in marine sediments. In this study we integrate diverse lines of evidence for identification and correlation of the oldest Toba tuff from four deep-sea sediment cores in the South China Sea and the Indian Ocean Basins. By employing high-resolution lithostratigraphic, magnetostratigraphic, and oxygen isotope stratigraphic records, we have (1) clarified the stratigraphic correlation, (2) refined the age, and (3) reestimated the eruptive volume of the early eruption of Toba.

\section{SAMPLES AND METHODS}

Three deep-sea sediment cores from an east-west transect in the South China Sea were selected to examine the lateral extent of eastward-dispersed Toba tuffs, over distances of 1800-2500 km from the source (Fig. 1). Detailed magnetostratigraphies and oxygen isotope stratigraphies of these cores have been documented elsewhere to provide a highresolution chronostratigraphic framework (Jian et al., 2000; Shyu et al., 2001; Tian et al., 2002; Wei et al., 2003). In the uppermost sections of ODP Hole 1143A $\left(9.36^{\circ} \mathrm{N}\right.$, $\left.113.29^{\circ} \mathrm{E}\right)$, two discrete tephra layers with a thickness of $\sim 2 \mathrm{~cm}$ were identified at subdepths of 5.55 and 42.65 meters composite depth (mcd), respectively (Wang et al., 2000), the uppermost of which has been correlated to the youngest Toba tuff (Bühring et al., 2000). The abundance of volcanic particles in core $17957\left(10.90^{\circ} \mathrm{N}, 115.31^{\circ} \mathrm{E}\right)$ shows six major eruptive events since $1.4 \mathrm{Ma}$; among them, ash zone NB1 overlaps the Brunhes-Matuyama boundary at $795 \mathrm{~cm}$ (Wang, 2000) and thus is a likely candidate for correlation to the oldest Toba tuff. To check whether the oldest Toba tuff could be dispersed farther to the east, the vertical distribution of volcanic shards in core MD972142 $\left(12.69^{\circ} \mathrm{N}, 119.56^{\circ} \mathrm{E}\right)$ was examined at increments of $4 \mathrm{~cm}$ through a $60 \mathrm{~cm}$ interval between the Brunhes-Matuyama boundary at $3370 \mathrm{~cm}$ (Lee, 2000) and the Australasian microtektite layer at $3425 \mathrm{~cm}$ (Lee and Wei, 2000). Glass shards were collected from the two upper ash layers in ODP Hole 1143A and from individual disseminated ash intervals in cores 17957 and MD972142. The major element compositions of glass shards were analyzed with a JEOL JXA8900R electron microprobe analyzer using accelerating voltage of $15 \mathrm{kV}$ and beam current of $10 \mathrm{nA}$ with defocused 10 - $\mu \mathrm{m}$-diameter beam.

\section{STRATIGRAPHIC OCCURRENCE}

Lithostratigraphies, magnetostratigraphies, and oxygen isotope stratigraphies of four selected sites are integrated here to show the stratigraphic occurrences of tephra layers within the uppermost Matuyama chronozone (Fig. 2). The distinct layer of microtektites and the overlying Brunhes-Matuyama geomagnetic boundary provide two markers for reliable correlation between sites. Layers suspected to be the oldest Toba tuff were recovered between these two time-parallel stratigraphic horizons. In core MD972142, a glass 


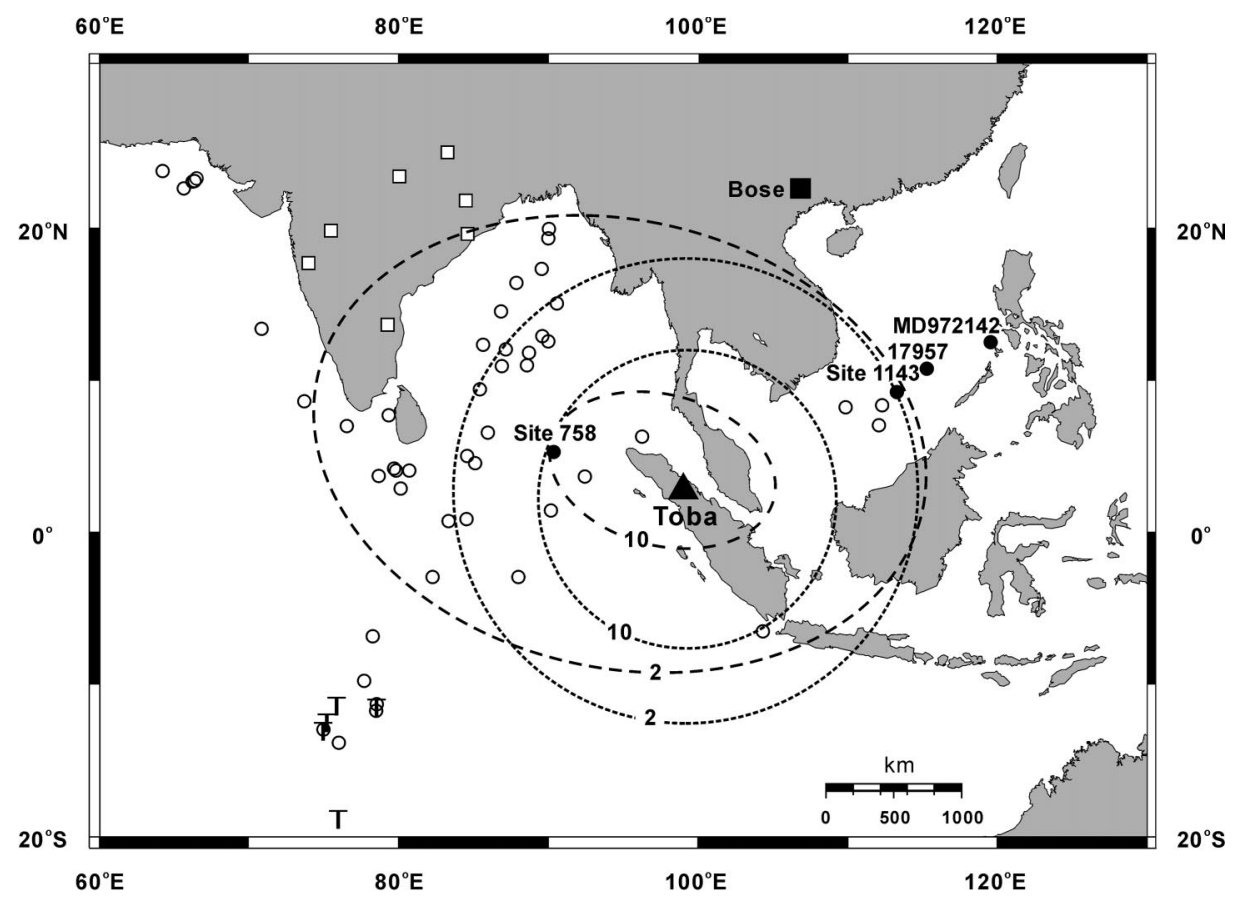

Figure 1. Map showing sites of cores containing Toba tephra fallout. Open dots indicate cores with tephra from youngest Toba tuff. Solid dots indicate cores used in this study. Short dashed circles show potential distribution of oldest Toba tuff tephra under assumption of symmetrical transport. Dashed ellipses show potential distribution of oldest Toba tuff tephra under assumption of similar dispersal features as seen for youngest Toba tuff tephra. Numbers indicate thickness of tephra in centimeters. Open squares mark terrestrial locations where Toba tephra has been found. Black square is archaeological site where tektites were found with Acheulean-like artifacts. $T$ indicates microtektites found in surface sediment.

abundance peak is located $39 \mathrm{~cm}$ below the Brunhes-Matuyama boundary and $16 \mathrm{~cm}$ above the microtektite layer. Similarly, in core 17957, a peak ash concentration is located slightly below the Brunhes-Matuyama boundary. Because of the strong overprinting of paleomagnetic signatures in all three holes at Site 1143 , it is only possible to indicate that a tephra layer falls within a geomagnetic transition at $\sim 42.5-43.8 \mathrm{mcd}$ (Wang et al., 2000). These results are in agreement with paleomagnetic studies on land, showing that the oldest Toba tuff occurs in an interval of reversed geomagnetic polarity (Knight et al., 1986; Diehl et al., 1987).

The tephrochronologic record of the past 5 m.y. at ODP Site 758 in the Indian Ocean has been used as a reference profile to correlate Quaternary eruptive events from the Toba caldera. Among them, three of the youngest four ash layers (A, C, and E) have been attributed to the quartz-bearing Toba tuffs erupted over the past 0.8 m.y. (Dehn et al., 1991): layer A correlated to youngest Toba tuff, layer $\mathrm{C}$ to middle Toba tuff, and layer $\mathrm{E}$ to oldest Toba tuff. Notably, a 13-cm-thick tephra layer D, which is just below the Brunhes-Matuyama boundary, but above layer E, has not been correlated to any Toba eruption (Dehn et al., 1991). By using the concentration spike of mi- crotektites as a reference horizon (Smit et al., 1991), the correlation of these two important tephra layers (D and E) can be clarified. Layer $\mathrm{D}$, located $\sim 8 \mathrm{~cm}$ above the peak abundance of microtektites, but $5 \mathrm{~cm}$ below the BrunhesMatuyama boundary, is now considered to be equivalent to the oldest Toba tuff recovered in cores MD972142 and 17957 from the South China Sea basin (Fig. 2).

\section{GEOCHEMISTRY OF GLASS SHARDS}

Electron-microprobe analyses of glass shards are shown in Table DR2. ${ }^{1}$ All of the rhyolitic shards from the South China Sea sediments are within a narrow range of high $\mathrm{SiO}_{2}$ (78 wt $\%$ ), high $\mathrm{K}_{2} \mathrm{O}(>5.0 \mathrm{wt} \%$ ), and low $\mathrm{Na}_{2} \mathrm{O}(<3.1$ wt $\%)$ contents. On a $\mathrm{CaO}-\mathrm{Na}_{2} \mathrm{O}-$ $\mathrm{K}_{2} \mathrm{O}$ ternary plot (Fig. 3), their geochemical characteristics are very similar to glass in layer D in ODP Site 758 and tephra in layer A (Site 758) and layer 1 (Site 1143). The latter two layers have previously been correlated

${ }^{1}$ GSA Data Repository item 2004009, Table DR1, core locations and identified stratigraphic horizons, and Table DR2, major element composition of Toba glass shards, is available online at www.geosociety.org/pubs/ft2004.htm, or on request from editing@geosociety.org or Documents Secretary, GSA, P.O. Box 9140, Boulder, CO 803019140, USA. with the youngest Toba tuff (Dehn et al., 1991; Bühring et al., 2000). The youngest and oldest Toba tuffs are thus very similar; their major element compositions show nearly complete overlap. As expected, layer E of Site 758 can be easily distinguished from the other layers by its relatively lower $\mathrm{K}_{2} \mathrm{O}$ and higher $\mathrm{CaO}$ and $\mathrm{Na}_{2} \mathrm{O}$ contents.

\section{REFINED CHRONOLOGY}

In all the sedimentary records, the inferred oldest Toba tuff layers fall within the deglaciation that occurred during the transition from marine oxygen isotope stage 20 to 19 (Fig. 2). More precisely, the level is between oxygen isotope events 19.3 (782 ka) and 20.2 (793 ka). Against the astronomically tuned time scale developed by Bassinot et al. (1994), age estimates for each core were calculated by linear interpolation between these two isotopic events. The ash layers in the four cores yielded an average age of $788.0 \pm 2.2 \mathrm{ka}$. This astronomically calibrated age is in good agreement with the ${ }^{39} \mathrm{Ar} /{ }^{40} \mathrm{Ar}$ age of $800 \pm 20 \mathrm{ka}$ for layer D of ODP Site 758 (Hall and Farrell, 1995), but is younger than the commonly cited ${ }^{39} \mathrm{Ar} /{ }^{40} \mathrm{Ar}$ age of $840 \pm 30 \mathrm{ka}$ (Diehl et al., 1987).

\section{DISCUSSION AND CONCLUSIONS}

Our results indicate that the rhyolitic glass shards of the first Toba eruption (oldest Toba tuff) were dispersed more than $3300 \mathrm{~km}$ from source. Fallout was most likely derived from coignimbrite clouds that drifted over both the Indian Ocean and the South China Sea, producing an extensive ash blanket that may have been comparable in size to that of the youngest Toba eruption. To our knowledge, ODP Site 1143 is the easternmost location in which the youngest Toba tuff has been documented (Bühring et al., 2000): our findings extend the eastern dispersal of the oldest Toba tuff even beyond this site. However, in the Indian Ocean, only one site with the oldest Toba tuff (on the Ninetyeast Ridge: Site 758, layer D) has been identified, and thus evaluation of the westward dispersal is more difficult. This 13$\mathrm{cm}$-thick oldest Toba tuff layer is similar in thickness to the youngest Toba tuff layers $(\sim 10 \mathrm{~cm})$ in the northeastern Indian Ocean (Ninkovich et al., 1978; Gasparotto et al., 2000). Assuming similar dispersal processes, it is likely that more distal ash locations of the oldest Toba tuff in the India Ocean occur at levels not yet recovered by coring.

The correlation of layer D in Site 758 to the oldest Toba tuff, which we recommend, confirms overlapping geochemical characteristics of glass shards between the youngest and oldest Toba tuffs. Rhyolitic glass shards in abyssal sediments of the central Indian Basin 


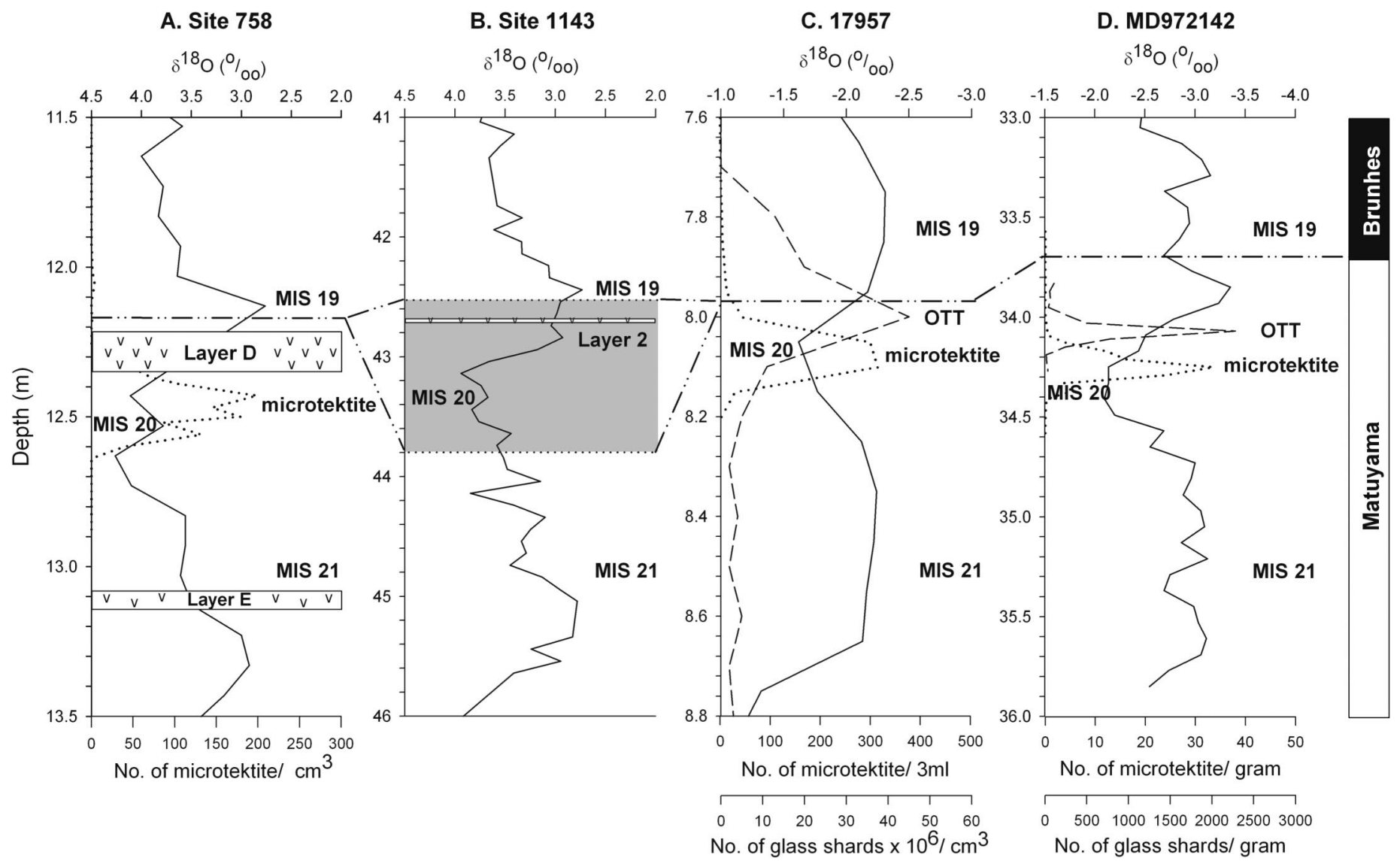

Figure 2. Stratigraphic occurrences of volcanic ashes and microtektites in cores of (A) Site 758, (B) Site 1143, (C) 17957, and (D) MD972142 for interval between marine isotope stages (MIS) 19 and 21 . Solid curves represent $\delta^{18} \mathrm{O}$ profiles, dotted lines correspond to abundance of microtektites, and dashed lines show abundance of glass shards. Dash-dotted line shows correlation of Brunhes-Matuyama boundary between sites. At Site 1143 overprinting of paleomagnetic signal does not allow for precise Brunhes-Matuyama boundary (gray zone). See Table DR1 (see footnote 1) for data sources.

have been assigned to those of fall deposits from the youngest Toba eruption (Pattan et al., 1999). By using layer E in Site 758 as the oldest Toba tuff glass composition, Pattan et al. (1999) inferred that all of these southwestward-dispersed glasses were from the youngest Toba event. A well-preserved ablated tektite and 33 microtektite grains from surficial sediments $(<30 \mathrm{~cm}$ in depth) have been collected from the investigated region (Fig. 1; Prasad and Rao, 1990; Prasad, 1994). The presence of tektites suggests that some of the rhyolitic shards between $\sim 12^{\circ} \mathrm{S}$ and $17^{\circ} \mathrm{S}$ in the Indian Ocean may be associated with the oldest Toba tuff.

Correlations of Toba tephra based on the use of layer E (Site 758), which suggest that only the $74 \mathrm{ka}$ Toba tephra is present across the Indian subcontinent, must now be considered suspect based on our results (Shane et al., 1995; Westgate et al., 1998). The possible presence of the oldest Toba tuff on the Indian subcontinent might shed light on the archaeological controversy concerning the ages of Acheulean stone artifacts dated by their stratigraphic association with respect to Toba deposits (Mishra and Rajaguru, 1996). Evidence for earlier dispersal to Asia has come from the discovery of Acheulean-like artifacts associated with $803 \mathrm{ka}$ tektites in the Bose Basin, south China (Fig. 1; Hou et al., 2000). The temporal proximity of Australasian tektites to the oldest Toba tuff offers a valuable time marker to enhance the chronological control within this age range.

The new correlations of the oldest Toba tuff in the South China Sea and possible widespread dispersal in the Indian Ocean allow for a reevaluation of the magnitude of the Toba eruption at $788 \mathrm{ka}$. A major difficulty in estimating eruptive volumes is extrapolation beyond the preserved area of the deposits. The youngest Toba eruption provides a basis for assessment of the atmospheric transport of tephra from large explosive eruptions in this area. By using the revised distribution of the youngest Toba tuff ash (Fig. 1) in combination with the exponential thinning model of Pyle (1989), the tephra-fall volume is estimated to be $865 \mathrm{~km}^{3}$ DRE, similar to that found in previous studies (Ninkovich et al., 1978; Rose and Chesner, 1987). By scaling the thickness of the oldest Toba tuff and youngest Toba tuff and assuming similar deposit morphology, we obtain an estimated volume in the range of $310-590 \mathrm{~km}^{3}$ DRE. Combining the landbased ignimbrite volume and ash fall together, the total volume of the oldest Toba tuff is at least $800-1000 \mathrm{~km}^{3}$ of dense rhyolitic magma.

The youngest Toba eruption has been proposed as a triggering mechanism for the onset of large-scale glaciation, which brought the last interglacial stage (marine isotope stage [MIS] 5) to its end (Rampino and Self, 1992, 1993). The coincidence of the oldest Toba tuff with the transition from a glacial stage (MIS 20) to an interglacial stage (MIS 19), however, appears to be an opposite effect. Although the estimated volume of the oldest Toba eruption is not as large as the youngest Toba, they are both enormous eruptions involving discharges of $10^{3} \mathrm{~km}^{3}$ of magma. However, the warming trend following the supereruption of the oldest Toba tuff appears to suggest that factors other than volcanism have played more influential roles in governing glacial to interglacial transitions in the Quaternary.

\section{ACKNOWLEDGMENTS}

This work is a contribution to the Taiwan IMAGES Program. We are grateful to the Gulf Coast Repository 

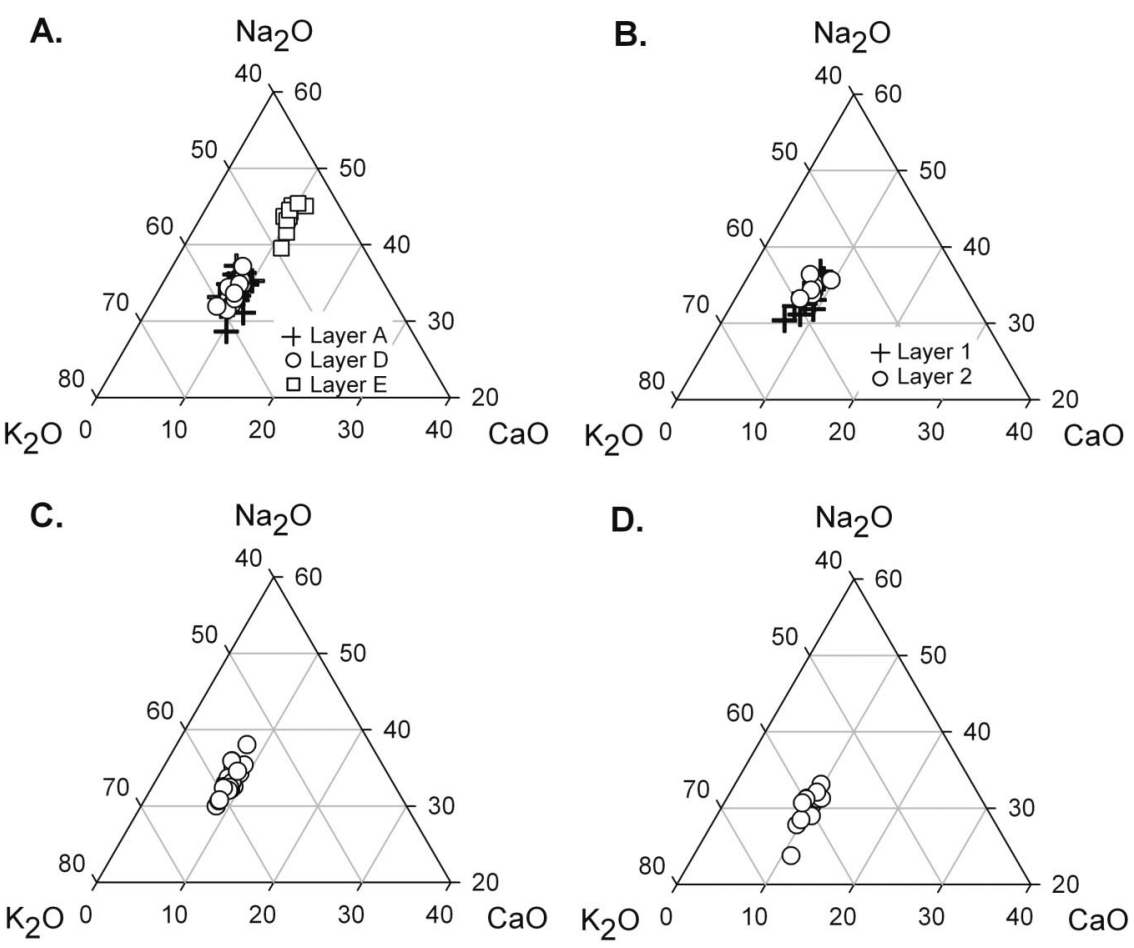

Figure 3. Partial plot of $\mathrm{CaO}-\mathrm{Na}_{2} \mathrm{O}-\mathrm{K}_{2} \mathrm{O}$ ternary diagram showing glass compositional similarities and differences between tephra samples from (A) Site 758, (B) Site 1143, (C) 17957, and (D) MD972142. Crosses represent youngest Toba tuff tephra from Sites 758 and 1143. Open squares represent tephra previously correlated to oldest Toba tuff. Open circles represent tephra correlated to oldest Toba tuff on basis of this study. Note similarity in composition between youngest and oldest Toba tuffs.

of the Ocean Drilling Program and Min-Pen Chen for providing samples from Site 1143 and Core 17957, respectively. This research was supported by National Science Council of Taiwan grants 90-2811-M-001009 and 90-2116-M-002-019.

\section{REFERENCES CITED}

Bassinot, F.C., Labeyrie, L.D., Vincent, E., Quidelleur, X., Shackleton, N.J., and Lancelot, Y., 1994, The astronomical theory of climate and the age of the Brunhes-Matuyama magnetic reversal: Earth and Planetary Science Letters, v. 126, p. 91-108.

Bühring, C., Sarnthein, M., and Leg 184 Shipboard Scientific Party, 2000, Toba ash layers in the South China Sea: Evidence of contrasting wind directions during eruption ca. 74 ka: Geology, v. 28 , p. $275-278$

Chesner, C.A., Rose, W.I., Deino, A., Drake, R., and Westgate, J.A., 1991, Eruptive history of Earth's largest Quaternary caldera (Toba, Indonesia) clarified: Geology, v. 19, p. 200-203.

Dehn, J., Farrel, J.W., and Schmincke, H.-U., 1991, Neogene tephrochronology from Site 758 on northern Ninetyeast Ridge: Indonesian arc volcanism of the past $5 \mathrm{Ma}$, in Weissel, J., Peirce, J., et al., Proceedings of the Ocean Drilling Program, Scientific results, Volume 121: College Station, Texas, Ocean Drilling Program, p. 273295.

Diehl, J.F., Onstott, T.C., Chesner, C.A., and Knight, M.D., 1987, No short reversals of Brunhes age recorded in the Toba tuffs, north Sumatra, Indonesia: Geophysical Research Letters, v. 14, p. 753-756.

Gasparotto, G., Spadafora, E., Summa, V., and Tateo, F, 2000, Contribution of grain size and compositional data from the Bengal Fan sediment to the understanding of Toba volcanic event: Marine Geology, v. 162 , p. 561-572.
Hall, C.M., and Farrell, J.W., 1995, Laser ${ }^{40} \mathrm{Ar} /{ }^{39} \mathrm{Ar}$ ages of tephra from Indian Ocean deep-sea sediments: Tie points for the astronomical and geomagnetic polarity time scales: Earth and Planetary Science Letters, v. 133, p. 327-338.

Hou, Y., Potts, R., Yuan, B., Guo, Z., Deino, A., Wang, W., Clark, J., Xie, G., and Huang, W., 2000, Mid-Pleistocene Acheulean-like stone technology of the Bose Basin, south China: Science, v. 287, p. 1622-1626.

Jian, Z., Wang, P., Chen, M.-P., Li, B., Zhao, Q., Bühring, C., Laj, C., Lin, H.-L., Pflaumann, U., Bian, Y., Wang, R., and Cheng, X., 2000, Foraminiferal responses to major Pleistocene paleoceanographic changes in the southern South China Sea: Paleoceanography, v. 15, p. 229-243.

Knight, M.D., Walker, G.P.L., Ellwood, B.B., and Diehl, J.F., 1986, Stratigraphy, paleomagnetism, and magnetic fabric of the Toba tuffs: Constraints on the sources and eruptive styles: Journal of Geophysical Research, v. 91, p. $10,355-10,382$.

Lee, M.-Y., and Wei, K.-Y., 2000, Australasian microtektites in the South China Sea and the West Philippine Sea: Implications for the age, size and location of impact crater: Meteoritics and Planetary Science, v. 35, p. 1151-1155.

Lee, T.-Q., 2000, Geomagnetic secular variation of the last one million years recorded on core MD972142 from the southeastern South China Sea: Geological Society of China Journal, v. 43, p. $423-433$.

Mishra, S., and Rajaguru, S.N., 1996, Comment on new geochemical evidence for the youngest Toba tuff in India: Quaternary Research, v. 46, p. $340-341$.

Ninkovich, D., Shackleton, N.J., Abdel-Monem, A.A., Obradovitch, J.D., and Izett, G., 1978, K-Ar age of the late Pleistocene eruption of Toba, north Sumatra: Nature, v. 276, p. 574-577.
Nishimura, S., Abe, E., Yokoyama, T., Wirasantosa, S., and Dharma, A., 1977, Danau Toba-The outline of Lake Toba, North Sumatra, Indonesia: Paleolimnology of Lake Biwa and the Japanese Pleistocene, v. 5, p. 313-332.

Pattan, J.N., Shane, P., and Banakar, V.K., 1999, New occurrence of youngest Toba tuff in abyssal sediments of the central Indian Basin: Marine Geology, v. 155 , p. 243-248.

Prasad, M.S., 1994, New occurrences of Australasian microtektites in the central Indian basin: Meteoritics, v. 29, p. 66-69.

Prasad, M.S., and Rao, P.S., 1990, Tektites far and wide: Nature, v. 347, p. 340.

Pyle, D.M., 1989, The thickness, volume and grainsize of tephra fall deposits: Bulletin of Volcanology, v. 51, p. 1-15.

Rampino, M.R., and Self, S., 1992, Volcanic winter and accelerated glaciation following the Toba supereruption: Nature, v. 359 , p. 50-52.

Rampino, M.R., and Self, S., 1993, Climatevolcanism feedback and the Toba eruption of $\sim 74,000$ yr ago: Quaternary Research, v. 40, p. $269-280$.

Rose, W.I., and Chesner, C.A., 1987, Dispersal of ash in the great Toba eruption: Geology, v. 15, p. 913-917.

Shane, P., Westgate, J., Williams, M., and Korisettar, R., 1995, New geochemical evidence for the youngest Toba tuff in India: Quaternary Research, v. 44, p. 200-204.

Shyu, J.-P., Chen, M.-P., Shieh, Y.-T., and Huang, C.K., 2001, A Pleistocene paleoceanographic record from the north slope of the Spratly Islands, southern South China Sea: Marine Micropaleontology, v. 42, p. 61-93.

Smit, J., van Bijden, A.J.M., and Troelstra, S.R., 1991, Analysis of the Australasian microtektite event, the Toba Lake event, and the Cretaceous/Paleogene boundary, Eastern Indian Ocean, in Weissel, J., Peirce, J., et al., Proceedings of the Ocean Drilling Program, Scientific results, Volume 121: College Station, Texas, Ocean Drilling Program, p. 489-503.

Tian, J., Wang, P., Cheng, X., and Li, Q., 2002, Astronomically tuned Plio-Pleistocene benthic $\delta^{18} \mathrm{O}$ record from the South China Sea and Atlantic-Pacific comparison: Earth and Planetary Science Letters, v. 203, p. 1015-1029.

Wang, P., Prell, W.L., Blum, P., et al., 2000, Proceedings of the Ocean Drilling Program, Initial reports, Volume 184: College Station, Texas, Ocean Drilling Program, $77 \mathrm{p}$.

Wang, R., 2000, Pleistocene tephrochronology from the Spratly Islands of the South China Sea and its geologic implication: Marine Geology and Quaternary Geology, v. 20, p. 51-55 (in Chinese).

Wei, K.-Y., Chiu, T.-C., and Chen, Y.-G., 2003, Toward establishing a marine proxy record of the East Asian summer for the late Quaternary: Marine Geology (in press).

Westgate, J., Shane, P., Pearce, N., Perkins, W., Korisettar, R., Chesner, C., Williams, M., and Acharyya, S., 1998, All Toba tephra occurrences across peninsular India belong to the 75,000 $\mathrm{yr}$ B.P. eruption: Quaternary Research, v. 50, p. $107-112$.

Zielinski, G.A., Mayewski, P.A., Meeker, L.D., Whitlow, S., Twickler, M.S., and Taylor, K., 1996, Potential atmospheric impact of the Toba megaeruption $\sim 71,000$ yr ago: Geophysical Research Letters, v. 23 , p. 837-840.

Manuscript received 8 June 2003

Revised manuscript received 16 September 2003 Manuscript accepted 17 September 2003

Printed in USA 